\title{
Optimizing social sustainability in walkable university campus: A comparison between the old and new campuses of Sulaimani University
}

\author{
Optimización de la sostenibilidad social en campus universitarios transitables: \\ una comparación entre los campus antiguos y nuevos de la Universidad de Sulaimani
}

Received: September 19, 2020

\begin{abstract}
Sustainable university campus design, to be walkable needs comprehensive planning that remarks the campuses as integrated whole; buildings and surroundings are considered as interrelated units rather than segmented parts. This paper shows a comparative study of the old and new campuses of Sulaimani University to compare social sustainability from the walkability point of view. Walkability as a feature of social sustainability is studied in this paper as walkability in built environment is assessed through four criteria which are connectivity, accessibility, safety/security and comfort. This paper has limited its empirical study to both connectivity and accessibility criteria in both campuses of Sulaimani University to test social sustainability in each campus. The aim of this paper is to achieve social sustainable campus design from the walkability point of view. The results showed that a compact campus design achieves both accessibility and connectedness rather than the linear design in means of social sustainability.
\end{abstract}

Abstract

Keywords: walkability; sustainability; sustainable campus; social connectedness; campus accessibility.

\section{Introduction}

University campus as a vital built environment needs a layout design to sketch out the basis for planning and requirements for its buildings and surrounding environments. The number of
Accepted: November 3, 2020

\author{
Written by: \\ Wrya Sabir Abdullah ${ }^{18,19}$ \\ https://orcid.org/0000-0001-5254-8148
}

\section{Resumen}

El diseño sustentable del campus universitario, para que sea transitable, necesita una planificación integral que considere los campus como un todo integrado; los edificios y los alrededores se consideran unidades interrelacionadas en lugar de partes segmentadas. Este artículo muestra un estudio comparativo de los campus antiguos y nuevos de la Universidad de Sulaimani para comparar la sostenibilidad social desde el punto de vista de la transitabilidad. La transitabilidad como una característica de la sostenibilidad social se estudia en este documento, ya que la transitabilidad en un entorno construido se evalúa a través de cuatro criterios que son conectividad, accesibilidad, seguridad y confort. Este artículo ha limitado su estudio empírico a criterios de conectividad y accesibilidad en ambos campus de la Universidad de Sulaimani para probar la sostenibilidad social en cada campus. El objetivo de este trabajo es lograr un diseño de campus socialmente sostenible desde el punto de vista de la transitabilidad. Los resultados mostraron que un diseño de campus compacto logra tanto la accesibilidad como la conectividad en lugar del diseño lineal en medios de sostenibilidad social.

Palabras claves: transitabilidad; sustentabilidad; campus sostenible; conectividad social; accesibilidad del campus.

students in universities' campus is in an increase which imposes careful attention to campus longterm planning and design (Biehle, 1991). This increasing in the number of students must be

\footnotetext{
${ }^{18} \mathrm{PhD}$. In Architecture Engineering Department of Architecture, University of Sulaimani, As Sulaymaneyah, Iraq.

${ }^{19} \mathrm{PhD}$. In Architecture Engineering Department of Architecture, Tishk International University Sulaimani, As Sulaymaneyah, Iraq.
} 


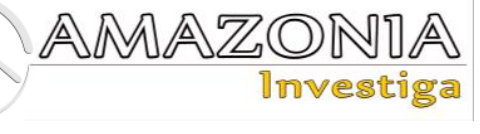

considered for the walkability criterion in the planning and design of campuses because walking forms the most frequent transformation type in the campus. Providing pleasant, walkable, comfortable, and accessible environments are highly required for all campus users. From the view of physical development planning, a wide and disperse planning contrast to the concept of campus in means of walkable and social sustainability as it is increasing the distance between areas; increasing reliance on vehicles; increasing air pollution; create accessibility problems, constrict infrastructure and facilities management, reduce energy efficiency, create poor social life with minimizing walkability (Mushtaha, 2015). It is believed that the planning and design quality of outdoor spaces should support the relationship between all users to improve the quality of campus life. Spaces should be designed and managed to serve the needs of users and be walkable and accessible to all people providing easy circulation, which makes the experience memorable and meaningful. A meaningful space is connecting the physical setting to the social context. Spaces that satisfy students' needs and offer meaning to them will be attractive and well utilized (Xi et al., 2012). Sustainable Campus has been everywhere to encourage the implementation of walkable transportation into the urban planning and design of the university campus to maximize user's health, their economical satisfaction, reduces pollution and improving better social activity in the campus (Alam, 2018). Designing and implementing walking transportation into campus planning and design can provide several advantages such as minimizing land used, reducing vehicle reliance, reduced resource consumption and pollution, encourage walking and cycling, increasing accessibility to facilities and service areas, more efficient provision of infrastructure and utilities, and re-develop used area. Litman 2019 shows that it is of particular concern to design scholars, developers, investors and others interested in sustainable and responsible property investing because of its potential social and environmental benefits (Litman, 2019).

\section{Walkability}

Walking is a common form of physical activity, which has a lot of social, health and recreational benefits. It is the most sustainable type of transport and one which has the least impact on the environment (Abdullah and Al-Qemaqchi, 2020). Walking is freely available to at least $96 \%$ of the population and walker-friendly places are also people-friendly places. Walking is studied as a way of achieving social sustainability in urban design. Many researchers recommend that walking can increase mental and physical health. Contemporary urban researchers recommend that the good design will encourage walking in built environments (Makki et al., 2012). All over the world, walking is the key mode of transportation-frequently representing the main mode for half of all transportation trips in the majority of the world. In addition to trips where walking is the main mode of transportation, walking comprises at least a portion of all other trips because people become pedestrians when they get out of vehicles or dismount from other modes of transportation (Ria, 2011). Abley defines walkability as "...the extent to which walking is readily available as a safe, connected, accessible and pleasant mode of transport" (Abley, 2005). While Alix Tier, indicates walkability as a measure that identifies the perceived friendliness, aesthetics and safety of an urban space (Tier et al. 2014). Southworth's study defines walkability as "the extent to which the built environment supports and encourages walking by providing for pedestrian comfort and safety, connecting people with varied destinations within a reasonable amount of time and effort and offering visual interest in journeys throughout the network" (Southworth, 2005). Walkability is a measure of how friendly an area is to walking. Walkability has many health, environmental, and economic benefits. Factors influencing walkability is related to the design of the urban structure which includes the presence or absence and quality of footpaths, sidewalks or other pedestrian rights-of-way, traffic and road conditions, land use patterns, building accessibility, and safety, among others as an important concept in sustainable urban design (Grignaffini et al. 2008). A healthy urban environment can be coined as environments that are "liveable, equitable and sustainable in which the built and natural environment support health, mobility, recreating, safety, social interaction and a sense of pride and cultural intimacy that is accessible to all the population" (Perrota et al, 2012). According to Christian's study 2010, walkability is a key factor in having a sustainable transportation network. It measures the friendliness of an area and considers many subjective factors in the process (Christian et al, 2010). Walkable areas help promote sustainable transportation, which is a concept that encourages transportation systems that have a low impact on our environment as well as increasing physical health and safety of the community. Therefore, walking is a common form of physical activity, which has both social and recreational physical activity, which has both 
social and recreational impacts. It is studied as a way of achieving sustainability from social activity point of view.

\section{Sustainable Campus}

Sustainable design is the philosophy of designing physical objects, the built environment, and services to comply with the principles of social, economic and environmental sustainability (McLennan, 2004). According to Cato 2009, a dynamic balance between economy and society, intended to generate long-term relationships between user and object/service and finally to be respectful and mindful of the environmental and social differences (Cato, 2009). Social sustainability is a process for creating sustainable, successful places that promote wellbeing, by understanding what people need from the places they live and work. Social sustainability combines design of the physical realm with design of the social world infrastructure to support social and cultural life, social amenities, and systems for citizen engagement and space for people and places to evolve (Colantonio and Dixon, 2009). According to Saffron's study 2011, social sustainability concerns how individuals, communities and societies live with each other and set out to achieve the objectives of development models which they have chosen for themselves, also taking into account the physical boundaries of their places and planet earth as a whole (Woodcraft et al, 2011). In this sense, social sustainability blends traditional social policy areas and principles, such as equity and health, with emerging issues concerning participation, needs, social capital, the economy, the environment, and more recently, with the notions of happiness, wellbeing and quality of life. Sustainable campus design needs comprehensive planning that considers universities' campus as a whole: buildings and its surrounding environment, and not segmented (Mushtaha, 2015). Universities with large numbers of academic staff, students, and administrative personnel and a variety of activities are comparable to small cities. So, walkability in the university campus is very important to help users have a healthy and social lifestyle in the campus. Universities should encourage people to shift their travel modes from cars to other types of travel, especially walking. So walkability is considered as a foundation for designing sustainable campus.

\section{Campus Social Connectedness}

Social connectedness is the measure of how people come together and interact. At an individual level, social connectedness involves the quality and number of connections one has with other people in a social circle of family, friends, and acquaintances. Going beyond these individual-level concepts, it involves relationships with beyond one's social circles and even to other communities. This connectedness, one of several components of community cohesion, provides benefits to both individuals and society (Zavaleta et al., 2014). Campus climate, an important social environmental factor that has an impact on students' university experiences, has been defined broadly by scholars as social connectedness which is the measure of how people come together and interact. Cress 2002 focused on the interpersonal interaction aspect of campus climate to distinguish it from campus culture. University campuses should possess a good social relationship for the users because campus climate would be the current attitudes, behaviors, standards and practice that employees and students have in an institution, which are usually linked to specific social groups (Cress, 2002).

\section{Campus Accessibility}

Accessible and universal design, also referred to as "accessibility", generally describes the extent to which elements and activities in the built environment are available to as large a crosssection of users as possible (Henry et al, 2014). The term "accessibility" is often used in reference to site, building, facility and other elements that provide access for individuals; here it is intended in the broader sense to include access for both the able-students and physically disabled ones. The University campus is committed to the best practices of accessibility in the design, construction, alteration and repair of spaces for use or occupancy by academic personnel, students, staff and public. As University campuses are comparable to small cities, walking in campuses is an ecological travel mode that is friendly to the environment and the economy can also promote the health of campus' users. To improve streets and walkways on campus, designers should have a good understanding of the needs of street and path users. In other words, planners should know which street factors affect walking conditions for various types of pedestrians (Asadi-Shekari et al., 2014). Grenis 2009 states that, University policy makers should encourage people to walk 


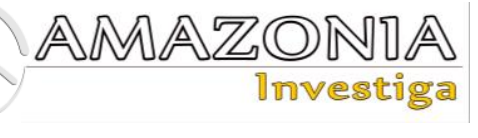

to create sustainable campuses with least possibilities of environmental, economic, and social problems. So, having a walkable-oriented campus should be the main interests of campus designers to help users have a healthy and social lifestyle in the campus (Grenis, 2009). Universities should encourage people to shift their travel modes from cars to other types of travel, especially walking. Providing walking facilities in addition to other effective policies (e.g., restricting automobile traffic within a campus and limiting automobile parking spaces on campus) can encourage the large number of students and users of the campus to walk to their destinations. Designing university campuses without socially walkable-oriented design encourages automobile transportation system inside the university campus which in result maximizes air pollution, high daily expenses and unhealthy transportation. A key foundation of sustainable campus design would lose when university campuses are not designed according to social and walkable criteria. The research hypothesizes that; "The increase length of street inside university campus, will reduce the students' social connectedness and walking accessibility that refer to social interaction as indication to social sustainability".

\section{Empirical study and Methodology}

In 1968, the first governmental university in Iraqi Kurdistan was founded and named the University of Sulaimani. It was the first university ever opened in the Kurdistan region of Iraq located in the city of Sulaymaniyah (U.O.S, 2002). This University has two campuses; the old campus was founded in 1968 which is located in a central part of the city and has a compact and cluster master plan design, while the new campus of the university is located at the outskirts of the city completed in 2012, and it has a linear type master plan design where teaching buildings and all other service buildings are distributed on the main linear street. The case is a comparative study of the two designed university campuses and the aim of the case is to show how social sustainability is optimized in walkable university campuses with regards to both connectivity and accessibility criteria. The new campus is designed on $(1,927,500 \mathrm{~m} 2)$ area and 18500 students were studying in (2018-2019). The study has observed three selected public spaces in each campus through video recording at same times for the purpose of revealing both gathering activity and accessibility of students to the selected spaces to indicate the degree of social connectedness inside the campuses. It also takes surveys of streets length and density inside both campuses to show the distances that students have to walk from gates to the public spaces inside each campus to show the degree of social accessibility in each campus.

\section{Data Calculation and Results}

Each campus of Sulaimani University was observed to know the social connectedness of students at three days of the week (Sunday, Tuesday and Thursday) concerning the beginning, medium and end days of the week at three times (10:00-10:30, 12:00-12:30 and 16:00-16:30) concerning three times of students' rest where the videos were recorded in spring season known as the best season for student gathering in public spaces. Observations of public sitting and gathering spaces were taken inside each campus to know the number of student grouping which is the main aspect of social connectedness inside university campus. Three public spaces are determined on the master plan of both old and new campuses shown in Figure 1 and 2. 


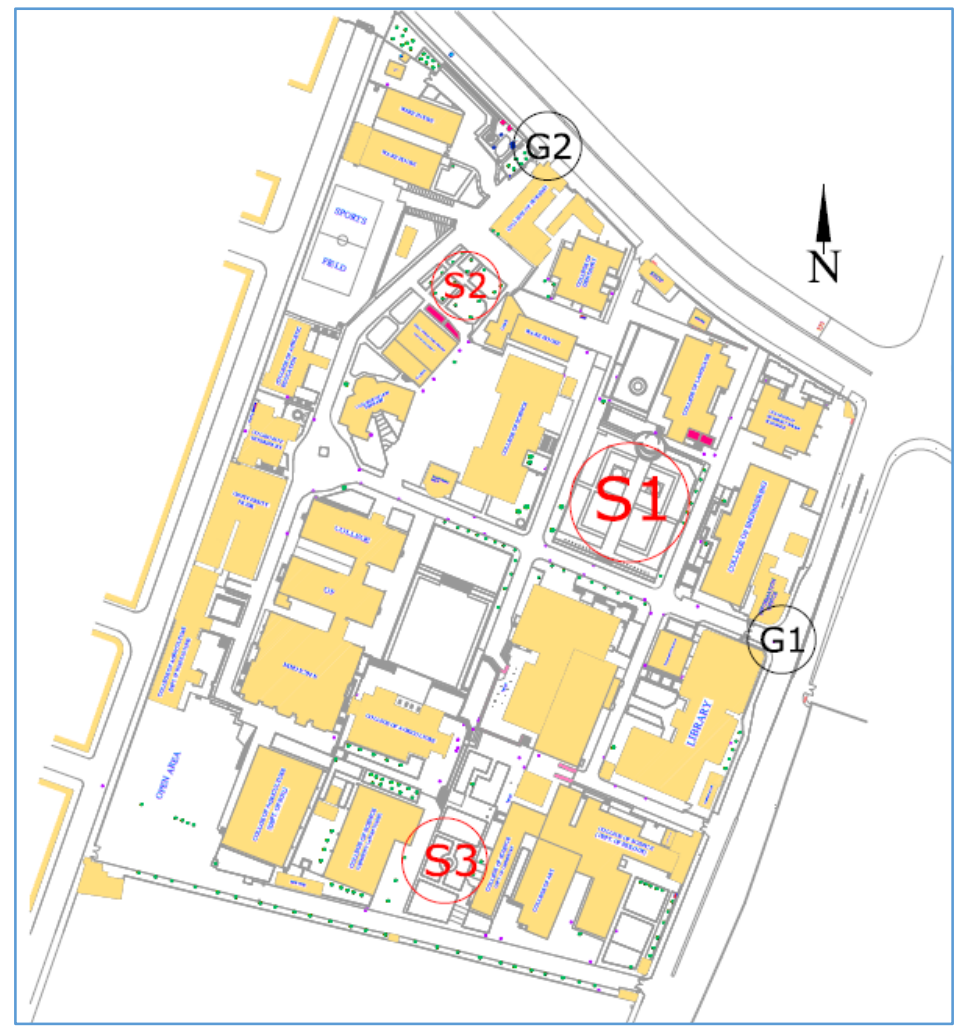

Figure 1. Site plan of the old campus showing the three Public Spaces, S1: 1st Public Space, S2: 2nd Public Space S3: 3rd Public Space, G1: Main Gate, G2: Secondary Gate.

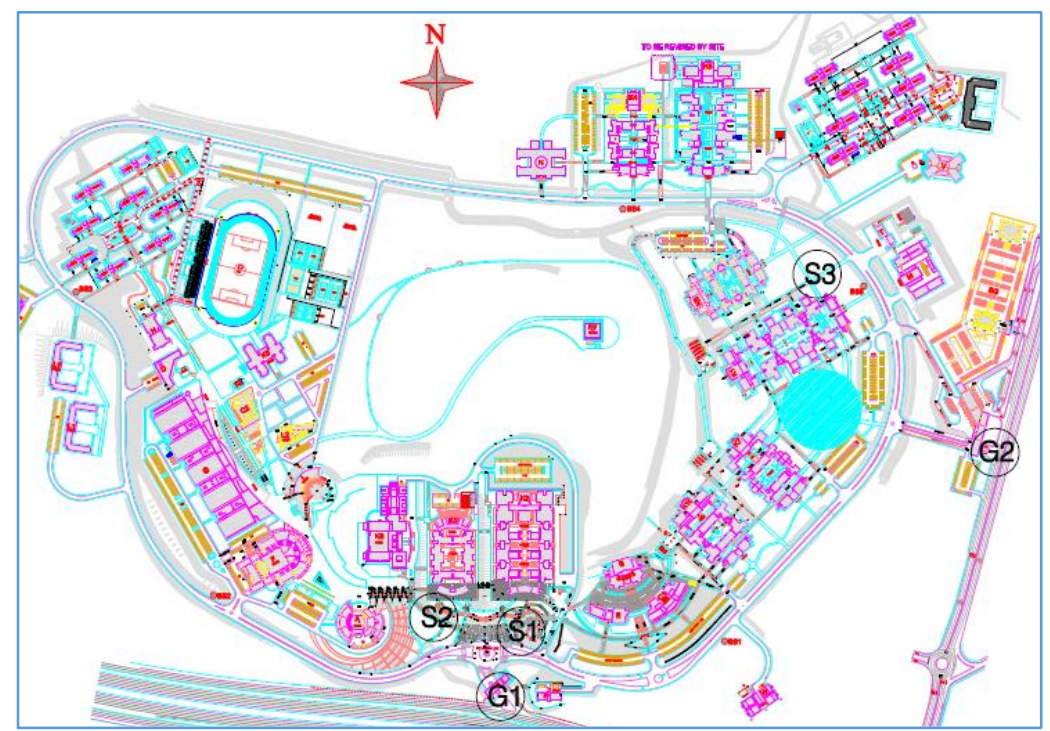

Figure 2. Site plan of the new campus of Sulaimani University. S1: 1st Public Space, S2: 2nd Public Space, S3: 3rd Public Space, G1: Main Gate and G2: Secondary gate.

Three public spaces are determined on both old and new campuses of Sulaimani University shown in Figure (1 and 2) and Figures (3-10) are sample of photos taken during video recording at each campus public spaces within the specified days and times. 


\section{ANAZOND用}

Tables (1, 2 and 3) show the density of student grouping in the three public spaces of the old campus determined in Figure (1). The density of students group for each public space is calculated as following:

$\gamma=\frac{\mathrm{b}}{\mathrm{a}}$

Table 1.

Number and Density of students' groups in the first public space (S1) of the old campus where (Area of S1 $\left.=2810 \mathrm{~m}^{2}\right)$

\begin{tabular}{|c|c|c|c|c|c|c|}
\hline Days & $\begin{array}{l}\text { Student } \\
\text { group No. at } \\
(10: 30)\end{array}$ & $\begin{array}{l}\text { Grouping } \\
\text { density in (S1) } \\
\text { at }(10: 30)\end{array}$ & $\begin{array}{l}\text { Student } \\
\text { group No. } \\
\text { at }(12: 30)\end{array}$ & $\begin{array}{l}\text { Grouping } \\
\text { density in (S1) } \\
\text { at }(12: 30)\end{array}$ & $\begin{array}{l}\text { Student } \\
\text { group No. at } \\
(\mathbf{1 0 : 3 0 )}\end{array}$ & $\begin{array}{l}\text { Grouping } \\
\text { density in (S1) } \\
\text { at }(16: 30)\end{array}$ \\
\hline Sunday & 35 & 0.0125 & 28 & 0.0100 & 25 & 0.009 \\
\hline Tuesday & 19 & 0.0068 & 13 & 0.0046 & 22 & 0.008 \\
\hline Thursday & 26 & 0.0093 & 7 & 0.0025 & 16 & 0.006 \\
\hline
\end{tabular}

Table 2.

Number and Density of students' groups in the second public space (S2) of the old campus where (Area of $S 2=860 \mathrm{~m} 2)$

\begin{tabular}{lllllll}
\hline Days & $\begin{array}{l}\text { Student } \\
\text { group No. at } \\
(\mathbf{1 0 : 3 0 )}\end{array}$ & $\begin{array}{l}\text { Grouping } \\
\text { density in } \\
\text { (S1) at } \mathbf{( 1 0 : 3 0 )}\end{array}$ & $\begin{array}{l}\text { Student } \\
\text { group No. } \\
\text { at (12:30) }\end{array}$ & $\begin{array}{l}\text { Grouping } \\
\text { density in } \\
\text { (S1) at }(\mathbf{1 2 : 3 0 )}\end{array}$ & $\begin{array}{l}\text { Student } \\
\text { group No. at } \\
(\mathbf{1 0 : 3 0 )}\end{array}$ & $\begin{array}{l}\text { Grouping } \\
\text { density in } \text { (S1) } \\
\text { at (16:30) }\end{array}$ \\
\hline Sunday & 2 & 0.0023 & 7 & 0.0081 & 5 & 0.0058 \\
Tuesday & 4 & 0.0047 & 5 & 0.0058 & 7 & 0.0081 \\
Thursday & 5 & 0.0058 & 4 & 0.0047 & 10 & 0.0116 \\
\hline
\end{tabular}

Table 3.

Number and Density of students' groups in the third public space (S3) of the old campus where (Area of S3 $=1975 \mathrm{~m} 2$ )

\begin{tabular}{|c|c|c|c|c|c|c|}
\hline Days & $\begin{array}{l}\text { Student } \\
\text { group No. at } \\
(\mathbf{1 0 : 3 0 )}\end{array}$ & $\begin{array}{l}\text { Grouping } \\
\text { density in } \\
\text { (S1) at } \\
(10: 30)\end{array}$ & $\begin{array}{l}\text { Student } \\
\text { group No. } \\
\text { at }(\mathbf{1 2 : 3 0 )}\end{array}$ & $\begin{array}{l}\text { Grouping } \\
\text { density in } \\
\text { (S1) at } \\
(12: 30)\end{array}$ & $\begin{array}{l}\text { Student } \\
\text { group No. } \\
\text { at (10:30) }\end{array}$ & $\begin{array}{l}\text { Grouping } \\
\text { density in (S1) } \\
\text { at }(\mathbf{1 6 : 3 0 )}\end{array}$ \\
\hline Sunday & 5 & 0.0025 & 2 & 0.0010 & 2 & 0.0010 \\
\hline Tuesday & 4 & 0.0020 & 0 & 0 & 3 & 0.0015 \\
\hline Thursday & 4 & 0.0020 & 5 & 0.0025 & 1 & 0.0005 \\
\hline
\end{tabular}

Table 4.

Number and Density of students' groups in the third public space (S1) of the new campus where (Area of S1 $=6142 \mathrm{~m} 2)$

\begin{tabular}{|c|c|c|c|c|c|c|}
\hline Days & $\begin{array}{l}\text { Student } \\
\text { group No. } \\
\text { at }(\mathbf{1 0 : 3 0 )}\end{array}$ & $\begin{array}{l}\text { Grouping } \\
\text { density in (S1) } \\
\text { at }(\mathbf{1 0 : 3 0 )}\end{array}$ & $\begin{array}{l}\text { Student } \\
\text { group No. at } \\
(12: 30) \\
\end{array}$ & $\begin{array}{l}\text { Grouping } \\
\text { density in (S1) } \\
\text { at }(12: 30)\end{array}$ & $\begin{array}{l}\text { Student } \\
\text { group No. } \\
\text { at }(\mathbf{1 0 : 3 0 )}\end{array}$ & $\begin{array}{l}\text { Grouping } \\
\text { density in (S1) } \\
\text { at }(\mathbf{1 6 : 3 0 )}\end{array}$ \\
\hline Sunday & 5 & 0.0008 & 3 & 0.0005 & 2 & 0.0003 \\
\hline Tuesday & 4 & 0.0006 & 2 & 0.0003 & 2 & 0.0003 \\
\hline Thursday & 3 & 0.0005 & 4 & 0.0006 & 2 & 0.0003 \\
\hline
\end{tabular}


Tables (4, 5 and 6) show the density of student grouping in the public spaces of the new campus determined in Figure. 2. Figures (3, 4, 5 and 6) are sample of photos of the gathering area of the old campus shown on Figure 1, taken during video recording observation at theses spaces within the specified days and times.

Table 5.

Number and Density of students' groups in the second public space (S2) of the new campus where (Area of $S 2=9400 \mathrm{~m} 2)$

\begin{tabular}{|c|c|c|c|c|c|c|}
\hline Days & $\begin{array}{l}\text { Student } \\
\text { group No. } \\
\text { at }(10: 30)\end{array}$ & $\begin{array}{l}\text { Grouping } \\
\text { density in (S1) } \\
\text { at }(10: 30)\end{array}$ & $\begin{array}{l}\text { Student } \\
\text { group No. at } \\
(12: 30)\end{array}$ & $\begin{array}{l}\text { Grouping } \\
\text { density in (S1) } \\
\text { at }(12: 30)\end{array}$ & $\begin{array}{l}\text { Student } \\
\text { group No. } \\
\text { at }(10: 30) \\
\end{array}$ & $\begin{array}{l}\text { Grouping } \\
\text { density in (S1) } \\
\text { at }(16: 30)\end{array}$ \\
\hline Sunday & 2 & 0.0002 & 4 & 0.0004 & 2 & 0.0006 \\
\hline Tuesday & 2 & 0.0002 & 3 & 0.0003 & 2 & 0.0004 \\
\hline Thursday & 3 & 0.0003 & 4 & 0.0004 & 2 & 0.0004 \\
\hline
\end{tabular}

Table 6.

Number and Density of students' groups in the third public space (S3) of the new campus where (Area of S3 $=20000 \mathrm{~m} 2$ )

\begin{tabular}{|c|c|c|c|c|c|c|}
\hline Days & $\begin{array}{l}\text { Student } \\
\text { group No. } \\
\text { at }(10: 30)\end{array}$ & $\begin{array}{l}\text { Grouping } \\
\text { density in }(\mathrm{S1}) \\
\text { at }(\mathbf{1 0 : 3 0 )}\end{array}$ & $\begin{array}{l}\text { Student } \\
\text { group No. at } \\
(12: 30)\end{array}$ & $\begin{array}{l}\text { Grouping } \\
\text { density in }(\mathrm{S} 1) \\
\text { at }(\mathbf{1 2 : 3 0 )}\end{array}$ & $\begin{array}{l}\text { Student } \\
\text { group No. } \\
\text { at }(10: 30)\end{array}$ & $\begin{array}{l}\text { Grouping } \\
\text { density in }(\mathrm{S1}) \\
\text { at }(16: 30)\end{array}$ \\
\hline Sunday & 5 & 0.00025 & 4 & 0.0002 & 2 & 0.0001 \\
\hline Tuesday & 2 & 0.0001 & 3 & 0.00015 & 0 & 0 \\
\hline Thursday & 1 & 0.00005 & 0 & 0 & 0 & 0 \\
\hline
\end{tabular}

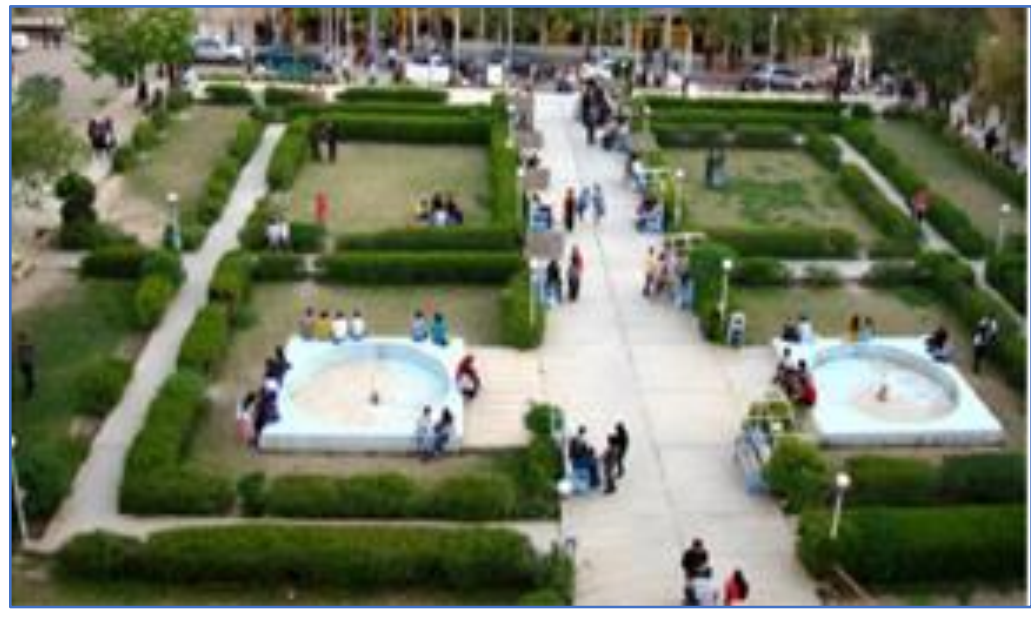

Figure 3. Photo taken at 10:30 at $\mathrm{S} 1$ on Sunday. 


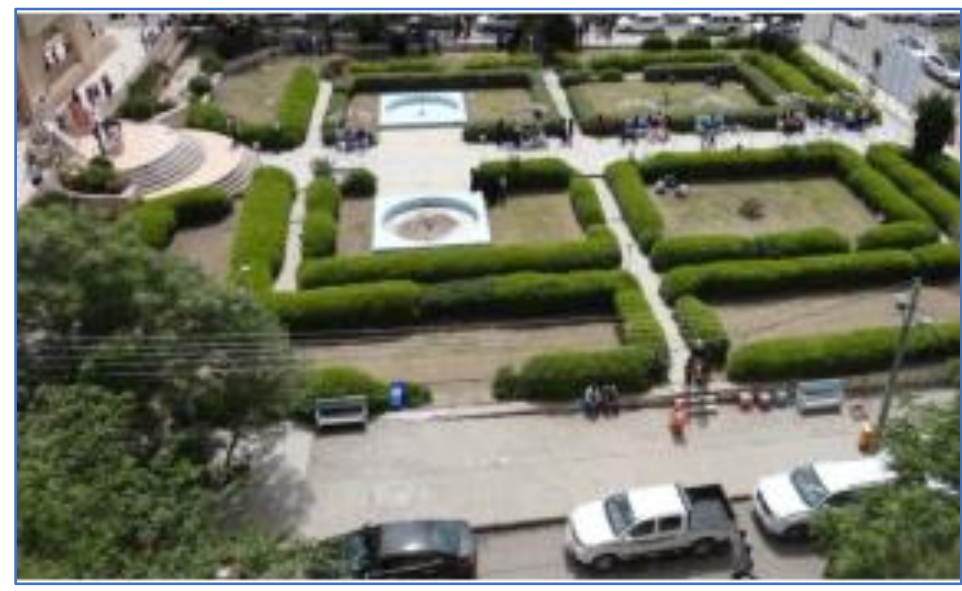

Figure 4. Photo taken at 12:30 at S1 on Sunday.

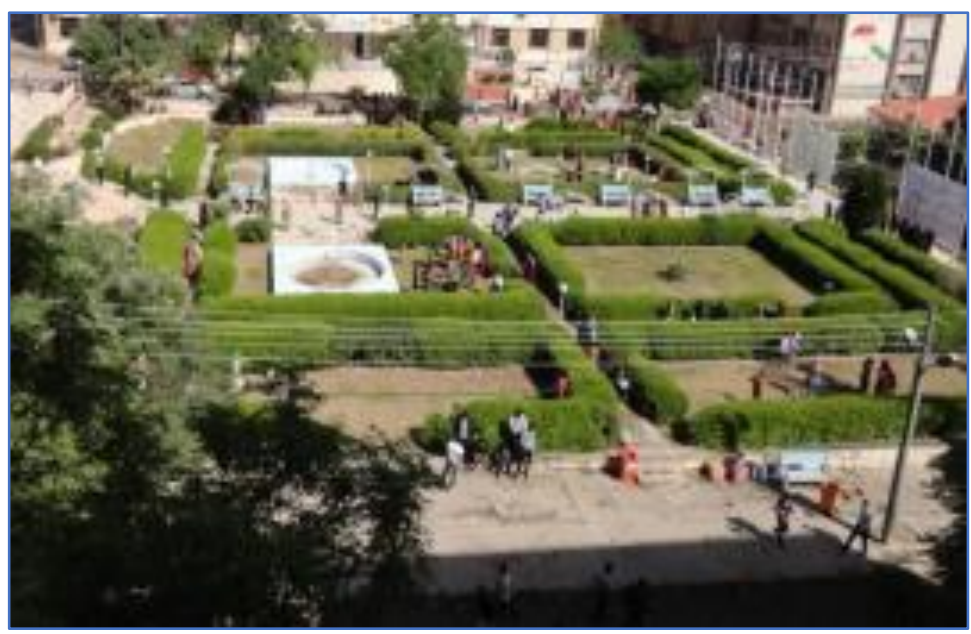

Figure 5. Photo taken at 10:30 at S1 on Tuesday.

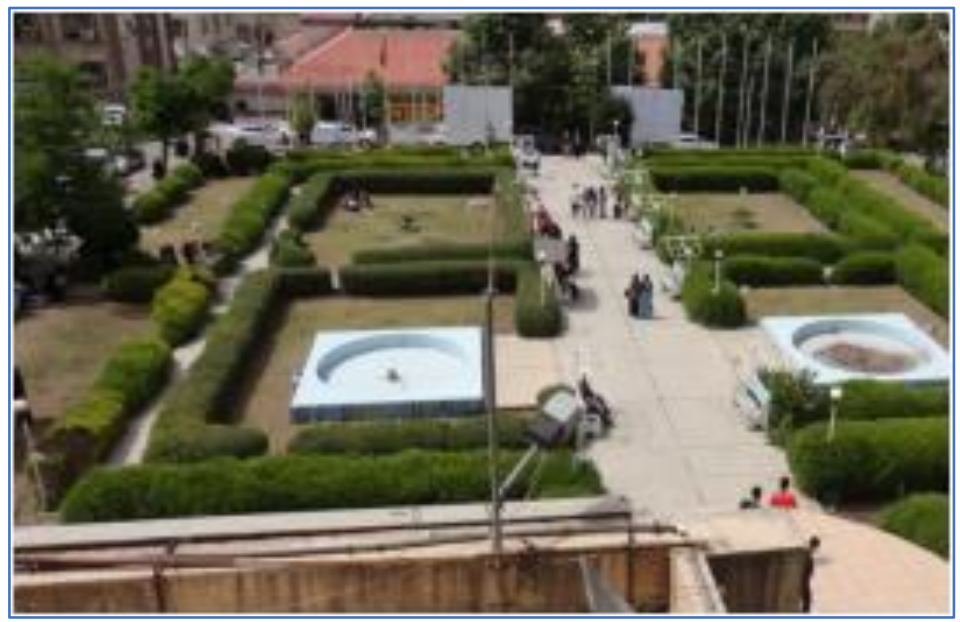

Figure 6. Photo taken at 16:30 at S1 on Sunday. 
Figures (7-10) are sample of photos of the gathering area taken during video recording observation at theses spaces within the specified days and times.
At the same times and dates observations have been made to three public spaces inside the new campus of the University of Sulaimani where the locations are determined on the master plan as shown in Figure 2.

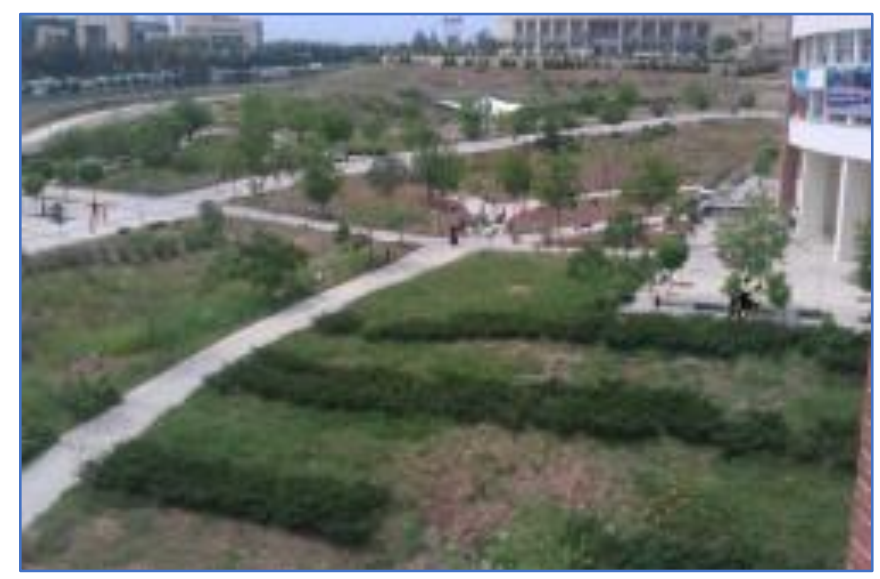

Figure 7. Photo taken at 10:30 at S1 on Tuesday.

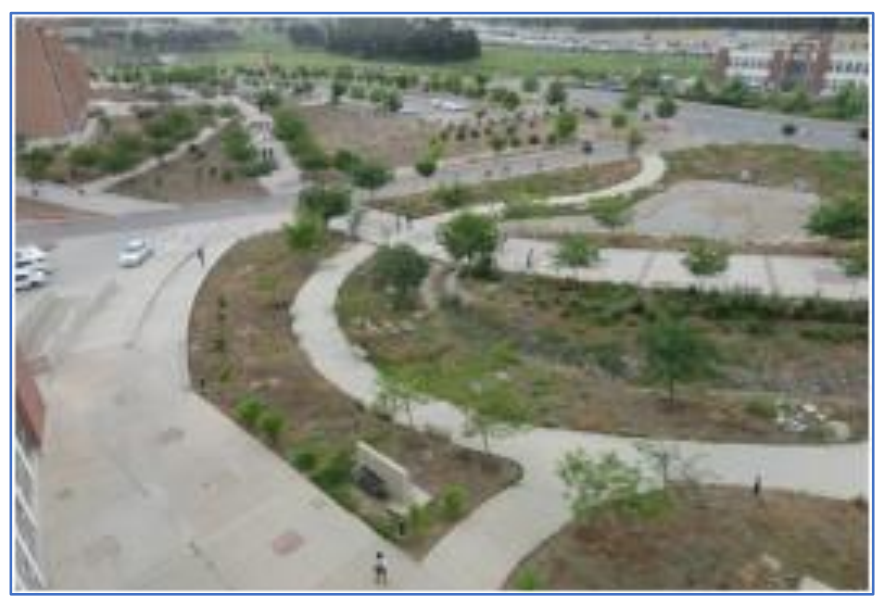

Figure 8. Photo taken at 12:30 at S1 on Sunday.

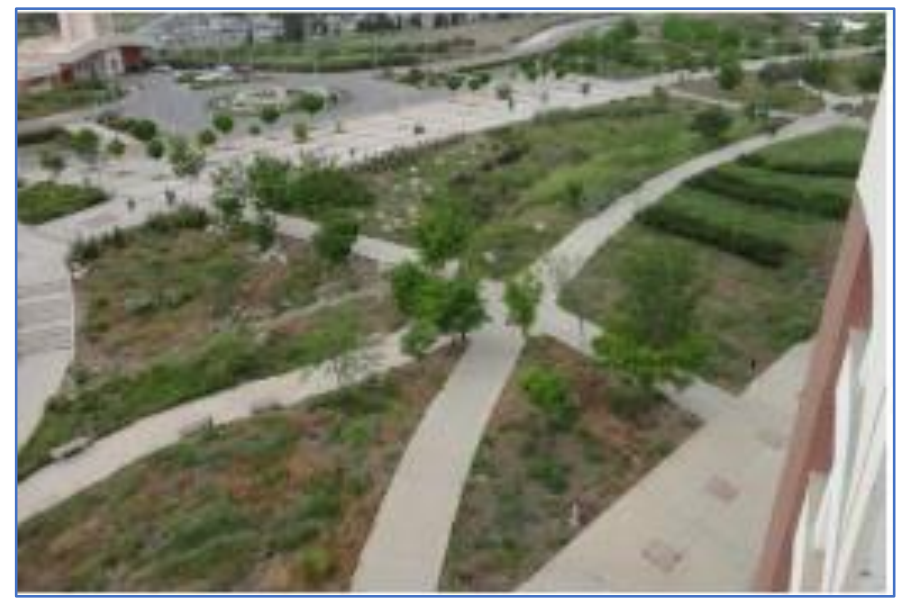

Figure 9. Photo taken at 16:30 at S1 on Sunday. 


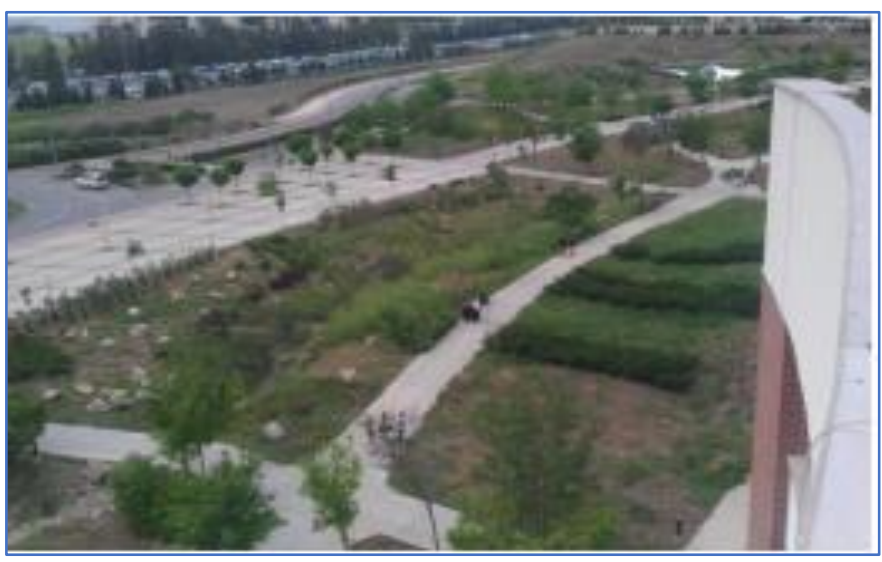

Figure 10. Photo taken at $16: 30$ at $\mathrm{S} 1$ on Sunday.

Regarding to walking accessibility, which is related to the walking activity of students, it is includes both walking speed and distance travelled by the students to reach their destinations. In order to assess this criterion of social sustainability, streets inside each campus have measured to know the distance which students have to walking and also students walking speeds are calculated in both campuses. Then comparison is made for walking accessibility for both campuses of the Sulaimani University. The two main gates of each campus are taken as the main references, then the density of streets to the three public spaces determined on the site plans of each campus as shown in Figure 1 and Figure 6 are found for both campuses and then compared. The density of streets for each public space is calculated as following:

$\alpha=\frac{\mathrm{d}}{\mathrm{a}}$

Where; $(\alpha)$ is street density, (d) is street length from gates to the public spaces and (a) is area of public space.

Table 7.

Street length, street density and average walking speed from main gates to the public spaces (S1, S2 and S3) in Old Campus.

\begin{tabular}{|c|c|c|c|c|c|c|c|c|c|}
\hline 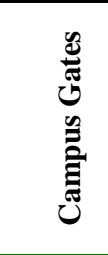 & 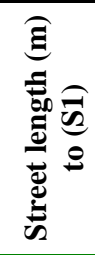 & 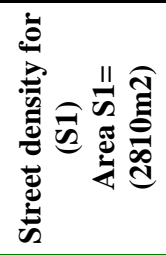 & 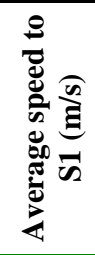 & 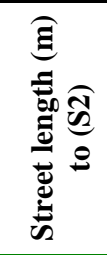 & 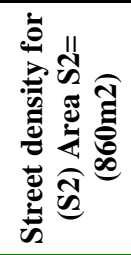 & 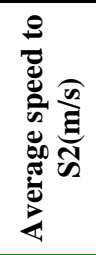 & 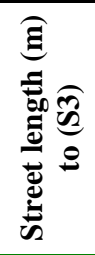 & 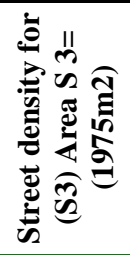 & 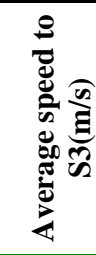 \\
\hline $\begin{array}{l}\text { From } \\
\text { Gate } 1\end{array}$ & 75 & 0.027 & 1.39 & 200 & 0.232 & 1.38 & 180 & 0.091 & 1.36 \\
\hline $\begin{array}{l}\text { From } \\
\text { Gate } 2\end{array}$ & 125 & 0.045 & 1.37 & 60 & 0.070 & 1.4 & 285 & 0.144 & 1.34 \\
\hline
\end{tabular}

To compare walking speed of the students in each campus, speed of each student is found using the following method:

$$
\mathrm{s}=\mathrm{d} / \mathrm{T}
$$

Where, (s) is the walking speed, (d) is the distance from gates to the public spaces and (D) is the time needed to reach the destination. Since the speed of pedestrians are not the same, mean speed must be found. For this purpose, speed of (125) pedestrians were found for each building and their mean speeds were found according to the following equation:

$$
\overline{\mathrm{s}}=\frac{\sum \mathrm{s}}{\mathrm{n}}
$$


Where, $(\overline{\mathrm{s}})$ is the mean speed, $\left(\sum \mathrm{s}\right)$ is the sum of all students speed (n) is the total number of students samples which is (125).
Tables (7 and 8) show the street density and length of streets from campus gates to the public spaces of the old and new campuses shown in Figure (1 and 2).

Table 8.

Street length, street density and average walking speed from main gates to the public spaces (S1, S2 and S3) in New Campus spaces (S1, S2 and S3) in Old Campus.

\begin{tabular}{|c|c|c|c|c|c|c|c|c|c|}
\hline 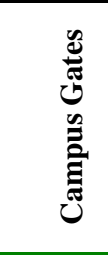 & 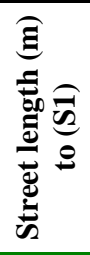 & 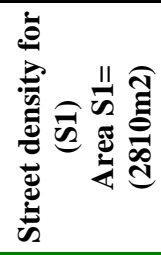 & 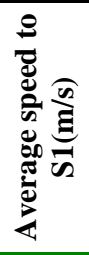 & 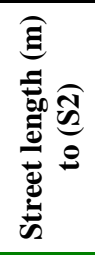 & 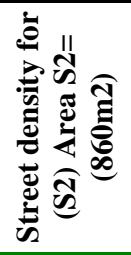 & 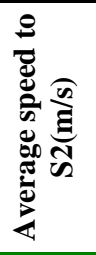 & 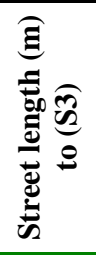 & 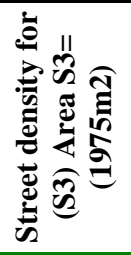 & 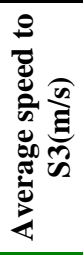 \\
\hline $\begin{array}{l}\text { From } \\
\text { Gate } 1\end{array}$ & 150 & 0.024 & 1.35 & 165 & 0.0175 & 1.34 & 1185 & 0.060 & 1.24 \\
\hline $\begin{array}{l}\text { From } \\
\text { Gate } 2\end{array}$ & 950 & 0.155 & 1.26 & 1200 & 0.128 & 1.23 & 360 & 0.0180 & 1.32 \\
\hline
\end{tabular}

According to the results of the calculations from the tables $(1-8)$, the following comparisons could be resulted;

- Student grouping density in the first public space (S1) in the old campus has the highest density on Sunday at 10:00am which is (0.0125) groups per the space area which is $(2810 \mathrm{~m} 2)$.

- While the student grouping density in the first public space (S1) in the new campus has the highest density on Sunday at 10:00am which is $(0.0008)$ groups per the space area which is $(6142 \mathrm{~m} 2)$.

- Comparing social connectedness in both campuses of Sulaimani University; grouping density in the public spaces of the old campus is nearly 16 times more than the grouping density in the public spaces of the new campus.

- The street density for the first public space (S1) of the old campus of the University has the least density which is $(0.027)$ per the space area $(2810 \mathrm{~m} 2)$ and the students need to walk $(75 \mathrm{~m})$ to reach (Space1) from (Gate 1) and (125m) from (Gate 2).

- While the street density for the second public space (S2) of the new campus of the University has the least density, which is (0.0175) per the space area $(9400 \mathrm{~m} 2)$ and students need to walk $(165 \mathrm{~m})$ to reach (Space2) from (Gate 1) and (950m) from (Gate 2).

- Regarding to the walking speed in each campus, the maximum walking speed in the old campus is $(1.4 \mathrm{~m} / \mathrm{s})$ to reach (Space 2$)$ while the maximum speed in the new campus is $(1.35 \mathrm{~m} / \mathrm{s})$ to reach (Space 1) the difference is. And the lowest walking speed in old campus is $(1.34 \mathrm{~m} / \mathrm{s})$ to reach (Space 3) while in the new campus it is $(1.23 \mathrm{~m} / \mathrm{s})$ to reach (Space 2). In average the walking speed to public spaces in the old campus is $(1.37 \mathrm{~m} / \mathrm{s})$, while in the new campus it is $(1.29 \mathrm{~m} / \mathrm{s})$.

Comparing social accessibility in both campuses of Sulaimani University; street density for the public spaces of the old campus is 1.6 times more than the street density in the public spaces of the new campus, but students need to walk $(682 \mathrm{~m})$ in average from gates to (S2) in the new campus, while students have to walk only $(100 \mathrm{~m})$ in average from gates to (S1) in the old campus. So, students in the new campus of the University have to walk 6.8 times more than students walking in the old campus. Also the average speed to reach the public space in the old campus is $(1.37 \mathrm{~m} / \mathrm{s})$ while in the new campus it is $(1.29 \mathrm{~m} / \mathrm{s})$ which indicates the accessibility in the old campus is more accessible than in the new campus where the speed is slower by $(0.08 \mathrm{~m} / \mathrm{s})$.

Concluding the results, the old campus of Sulaimani University has less street length, more walking speed and more students grouping density which increased students' social connectedness and social accessibility which refer to social sustainable design of the old campus compared to the new campus of Sulaimani University.

\section{Conclusions}

1. The results show the difference between both campuses design where the old campus 


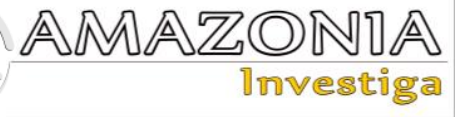

has been designed with more gathering spaces that encourages social connectedness and the compact design typology of the old campus also encourages optimum walking distance while the linear design typology of the new campus has discouraged the social connectedness since gathering areas are far from students teaching buildings which are not in walking distance range.

2. The old campus of Sulaimani University is designed more according to humanization standards, where walking activity is normal inside the campus as the design is a clustered design and all buildings, service buildings and public spaces are located on a main street inside the campus. While the new campus is designed on a large area and has a linear design that maximized the street lengths where walking is very difficult inside the campus and students prefer to stay within their buildings layouts.

3. In the old campus, public spaces are designed in central points between teaching buildings so that during the rests of students, most gathering and social connectedness of students occur which are key factors of social sustainability. While in the new campus public spaces are distributed according to the linear design where space is near to a building but far from other buildings which reduces social connectedness and gathering of students inside public spaces.

4. In the old campus, public spaces are designed in balanced distances between the two gates to achieve social accessibility which is a key factor to achieve social sustainability. While in the new campus public spaces are of a moderate distance from a gate but so far from the other due to the design type of the campus, which reduces the social accessibility to the public spaces.

\section{References}

Abdullah, W., \& Al-Qemaqchi, N. (2020). Simulation of Pedestrian Behaviour As Design Criteria For University Teaching Buildings. Amazonia Investiga, 9(26), 134-145. https://doi.org/10.34069/AI/2020.26.02.15

Retrieved from: https://www.amazoniainvestiga.info/index.php/a mazonia/article/view/1033/1025

Abley, S. (2010). Predicting Walkability. Walkability Scoping Paper, Living Streets Aotearoa (LSA), Walking Conference, James Cook Hotel Grand Chancellor, Wellington New Zealand.
Alam, M. I. (2018). A sustainable campus for the higher education institutions in the U.S. A thesis submitted to the graduate faculty in partial fulfillment of the requirements for the degree of MASTER OF SCIENCE, Iowa State University. Asadi-Shekari, Z.; Moeinaddini, M. \& Shah, M. Z. (2014). A pedestrian level of service method for evaluating and promoting walking facilities on campus streets. Land Use Policy journal, 38, pp. 175-193, DOI: 10.1016/j.landusepol.2013.11.007

Biehle, J. (1991). Successful Master Planning. Planning for Higher Education, 19 (4), pp. 21-26. Cato, M. S. (2009). Green Economics: An Introduction to theory, policy and practice. UK, London: Earthscan 2009, pp. 36-37. ISBN 9781-84407-571-3.

Christian, S., Cochrane, S., Creelman, M., d'Apollonia, L., Talbot, G. \& Wiggins, M. (2010). Studley Campus Walkability Assessment. Dalhouse University.

Colantonio, A. and Dixon, T. (2009). Measuring socially sustainable urban regeneration in Europe. Oxford Brookes University: Oxford Institute for Sustainable Development (OISD)

Cress, C. M. (2002). Campus climate. In A. M. Martinez, \& K. A. Renn (Eds.), Women in higher education: An encyclopedia, pp. 390-397. Santa Barbara, CA:ABC-CLIO Inc. DOI:10.1145/2596695.2596719

Grenis, B. (2009). Crosswalk Installation and Modification Guidelines. University of Iowa Campus.

Grignaffini, S., Cappellanti, S. \& Cefalo, A. (2008). Visualizing sustainability in urban conditions. WIT Transactions on Ecology and the Environment, Vol. 1, pp. 253-262, 10 Jun 2008.

Henry, S. L.; Abou-Zahra, S. \& Brewer, J. (2014). The role of accessibility in a universal. Litman, T. (2019). Evaluating Accessibility for Transport Activities: Measuring People's Ability to Reach Desired Goods and Activities. Victoria Transport Policy Institute.

Makki, S., Surat, M., Che-Ani, A.I., Farkisch, H. and Mokhtarian, H.R. (2012). The importance of design characteristics in walking from student's perspective: a case study in Universiti Kebangssn Malaysia. Journal of Building Performance, Vol 3 (1), pp. 42-49.

McLennan, J. F. (2004). The Philosophy of Sustainable Design. Ecotone Publishing Company LLC; F First Edition edition.

Mushtaha, Emad S. (2015) Status of International Sustainable Campuses Improvement of Walkability as a Prerequisite for Sustainability, Conference: Quality Assurance in Engineering Education,17-19 March 2015, University of Sharjah, Sharjah, UAE. 
Perrota, K., Campbell, M., Chirrey, S., Frank, L. and Chapman, J. (2012). The Walkable City: Neighbourhood Design and Preferences, Travel Choices and Health. Toronto: Toronto Public Health 2012.

Southworth, M. (2005). Designing the walkable city. Journal of Urban Planning and Development, 131(4), pp.246-257.

Tier, A., Wiitala, C., \& Domokos, S. (2014). Walkability on University Avenue. Dalhousie University Inspiring Minds.

U.O.S., University of Sulaimani. (2001-2002). The University of Sulaimani, Prospectus: Academic year 2001-2002. Sulaimani University Press. web. In Proceedings of the 11th Web for All Conference (W4A'14). ACM, New York, NY, Article 17, 4.

Woodcraft, S., Hackett, T. \& Caistor-Arendar, L. (2011). Design for Social Sustainability: A framework for creating thriving new communities. London: The Young Foundation. Xi, T., Ding, J., Jin, H. \& Mochida, A. (2012). Study on the outdoor thermal environment and thermal comfort around campus clusters in subtropical urban areas, Building and Environment Journal. 52. pp.162-170. DOI: 10.1016/j.buildenv.2011.11.006

Zavaleta, D.; Samuel, K. and Mills, C. (2014). Social isolation: A conceptual and measurement proposal (OPHI Working Paper No. 67), University of Oxford. 